\title{
ANALYSIS OF THE EDUCATIONAL SYSTEM OF THE KINGDOM OF BELGIUM WITH EMPHASIS ON THE FIELD OF TECHNICAL EDUCATION
}

\author{
Adriana NAGYOVÁ - Ján ZÁHOREC
}

\begin{abstract}
Quality of technical education is mainly dependent on the continuity of the content and implementation of a follow-up study of secondary schools to primary schools and institutions of higher education to the secondary ones. Particularly in natural and technical sciences it is necessary to continually improve both initial and follow-up educational levels and gradually transform the school system. In this contribution, the authors deal with the analysis of integration and status of the technical subjects at the secondary education level in the Belgium within the frame of international comparison of the Slovak and Belgian educational systems to assess the current level of quality of technical education in Slovakia and identify the areas that need to be focused on in the further increasing of technical education quality.
\end{abstract}

Key words: Belgian Educational System, Quality of Technical Education, School Subjects Technical Education and Technology.

\section{ANALÝZA ŠKOLSKÉHO SYSTÉMU BELGICKA S DÔRAZOM NA OBLASŤ TECHNICKÉHO VZDELÁVANIA}

\begin{abstract}
Abstrakt: Kvalita technického vzdelávania je závislá najmä od nadväznosti obsahu a realizácie štúdia stredných škôl na školy základné a vysokých škôl na školy stredné. Najmä v oblasti prírodných a technických vied je potrebné neustále zlepšovat' ako počiatočné, tak i nadväzujúce vzdelávacie stupne a postupne tak transformovat' školský systém. V príspevku sa autori zaoberajú analýzou začlenenia a postavenia technických vyučovacích predmetov na sekundárnom stupni vzdelávania $v$ Belgicku v rámci riešenia medzinárodnej komparácie hodnotenia súčasnej úrovne kvality technického vzdelávania na Slovensku a identifikáciu oblastí, na ktoré by bolo potrebné sa zamerat' $v$ rámci d’alšieho zvyšovania kvality technického vzdelávania.
\end{abstract}

Kl'účové slová: Belgický vzdelávaci systém, kvalita technického vzdelávania, vyučovacie predmety technická výchova a technika.

\section{1 Úvod}

Východiskovým bodom hodnotenia kvality a významnosti technického vzdelávania na jednotlivých stupňoch vzdelávacieho systému je poznanie jednotlivých aspektov, ktoré na kvalitu pôsobia. Je paradoxné, že súčasný stav technického vzdelávania, ktorý je výsledkom pokrokov vedy a objavov prírodných a technických vied, sa prejavuje znížením záujmu súčasnej mladej generácie, absolventov základných a stredných škôl o štúdium exaktných vied, a tiež o prácu vodvetviach technického a prírodovedného zamerania. Pokles počtu absolventov stredných škôl uchádzajúcich sa o štúdium prírodovedného či technického zamerania svedčí nielen o poklese záujmu o tieto disciplíny, ale aj o zvyšujúcej sa neoblúbenosti prírodovedných a technických vyučovacích predmetov a o oblúbenosti spoločensko-vedných a humanitných predmetov [1], [2]. Táto tendencia sa prejavuje nielen na Slovensku, ale aj $\mathrm{v}$ zahraničí.

Otázkami technického vzdelávania, ktoré by podl'a viacerých odborníkov $\mathrm{v}$ tejto oblasti malo byt' neoddelitel'nou súčast'ou všeobecného vzdelávania, sa zaoberala aj svetová organizácia pre vzdelávanie, vedu a kultúru UNESCO. Tá už v roku 1974 vyhlásila program, podl'a ktorého sú predmety technického charakteru organickou súčast'ou všeobecného vzdelania. Pričom na základe tohto programu by malo začiatkom 90 . rokov 20. storočia 38 krajín obsahovat' vo svojom školskom kurikule predmety technického charakteru [3]. Na Slovensku projekt Milénium, ako programový dokument $\mathrm{v}$ oblasti školstva poukazuje na opodstatnenost' všeobecného technického vzdelávania a jeho zastúpenia $\mathrm{v}$ učebných osnovách $\mathrm{v}$ rámci predmetu technická výchova na nižšom sekundárnom stupni školského systému. 
Význam všeobecného technického vzdelávania na nižšom sekundárnom stupni si uvedomujú i členské krajiny EÚ s výrazne lepšími ekonomickými a hospodárskymi výsledkami ako vykazuje Slovensko. Príkladom je Belgicko, konkrétne jeho región Flámsko. Flámska komunita v Belgicku vydala publikáciu (TOS 21 - Technika na školách 21. storočia) [4], v ktorej vel'ká skupina expertov voblasti technického vzdelávania komplexne analyzuje príslušné problémy na všetkých stupňoch škôl flámskeho vzdelávacieho systému. Už niekol'ko desat'ročí je Flámsko profilované ako jeden $z$ najbohatších regiónov Európy, kde si uvedomujú význam inžinierskych a technických inovácií, a toto uvedomenie nepochybne prispieva významným spôsobom k dosahovaným výsledkom. V mnohých prieskumoch verejnej mienky sa však preukázalo, že vo flámskej komunite sa mladí l'udia nijako zvlášt' nezaujímajú o techniku [5]. Na základe uvedených skutočností usudzujeme, že verejná podpora pre techniku nie je obzvláśt' vysoká. Vo Flámsku, ako aj v d’alších európskych krajinách sa v tomto smere vyvíjajú rôzne iniciatívy pre stredoškolskú mládež, a to zo strany vlády, priemyslu, univerzít, vysokých škôl, súkromných inštitúcií v snahe o zvýšenie technickej gramotnosti a zvýšenie záujmu o prírodné vedy a techniku [6]. Vzhl'adom $\mathrm{k}$ vyššie uvedeným problémom, nadväzujúc na predchádzajúce iniciatívy v skúmanej oblasti bol vytvorený vládny projekt „Technika na školách 21 . storočia“" (TOS21) [7], ktorého hlavnou úlohou je zvýšenie záujmu o techniku u detí navštevujúcich predprimárny stupeň vzdelávania, až po študentov navštevujúcich TOBO (Technické vzdelávanie na primárnej úrovni) a TOSO (Technické vzdelávanie na stredoškolskej úrovni). Základnú myšlienku projektu tvorí vízia zvyšovania povedomia o význame vedy a techniky od útleho veku ako aj počas celého obdobia ich školskej kariéry. Podl'a tvorcov uvedeného projektu sa len týmto spôsobom dá podporit' odstránenie nedostatku študentov v prírodovedne a technicky orientovaných študijných odboroch a následne $\mathrm{v}$ pracovných odvetviach tohto zamerania.

Počas vyučovania technickej výchovy v rámci systému vzdelávania v SR boli obdobia, ktoré sa ešte $\mathrm{v}$ súčasnosti prejavujú $\mathrm{v}$ zmysle negatívneho pohl'adu na predmet technická výchova, jeho nedocenenia a nepochopenia jeho funkcie pri zabezpečovaní trvalého hospodárskeho a ekonomického rastu spoločnosti. Prejavuje sa to nielen súčasným, vel’mi nízkym záujmom o štúdium prírodovedných a technických predmetov, ale aj $\mathrm{v}$ nedostatočnej vedomostnej úrovni uchádzačov o štúdium na výberových odboroch stredných škôl, slabou previazanost’ou obsahu vzdelávania na ZŠ so študijným obsahom predmetov stredných odborných škôl. Uvedené skutočnosti sa prejavujú aj na ZŠ a SŠ v SR v zníženej kvalite vyučovania predmetu technická výchova na nižšom sekundárnom stupni [8].

\section{Organizácia vzdelávania v Belgicku na sekundárnom stupni}

Vo Flámsku, ako aj $\mathrm{v}$ celom Belgicku sa základné vzdelávanie svojou organizáciou a realizáciou diferencuje od základného vzdelávania v Slovenskej republike tým, že spája predprimárne vzdelávanie (trvanie spravidla 3 roky) a primárne vzdelávanie (organizované prostredníctvom šiestich ročníkov ZŠ. Po ukončení ZŠ vo veku 12 rokov žiaci pokračujú vo vzdelávaní na SS̆. Na prvom stupni sekundárneho vzdelávania je hlavným ciel’om, aby študenti získali všeobecný prehl'ad zo všetkých oblastí. Druhý a tretí stupeň sekundárneho vzdelávania sa člení na štyri formy štúdia:

- Stredné všeobecné vzdelanie (ASO) - u nás to predstavujú gymnáziá, ktoré poskytujú vzdelanie tohto typu. Štúdium trvá 4 roky a jeho úlohou a ciel'om je pripravit' študentov na vysokoškolské vzdelávanie.

- Stredné technické vzdelanie (TSO) - štúdium trvá 4 roky a kladie dôraz na prenášanie teoretických poznatkov do praktických zručností. Zameriava sa taktiež na praktické kurzy s ciel'om pripravit' študentov tak pre profesionálne kariéry, ako aj na vyššie vzdelávanie.

- Stredné umelecké vzdelanie (KSO) - trvá 4 roky, kombinuje široké všeobecné vzdelanie s aktívnym umeleckým tréningom a pripravuje študentov bud' pre profesijnú dráhu alebo pre vyššie vzdelávanie.

- Stredné odborné vzdelanie (BSO) - môže trvat' až 5 rokov a vedie študentov $\mathrm{k}$ vzdelaniu súvisiacemu s ich budúcim povolaním. 
Obr. 1: Schéma školského systému v Belgicku [10]

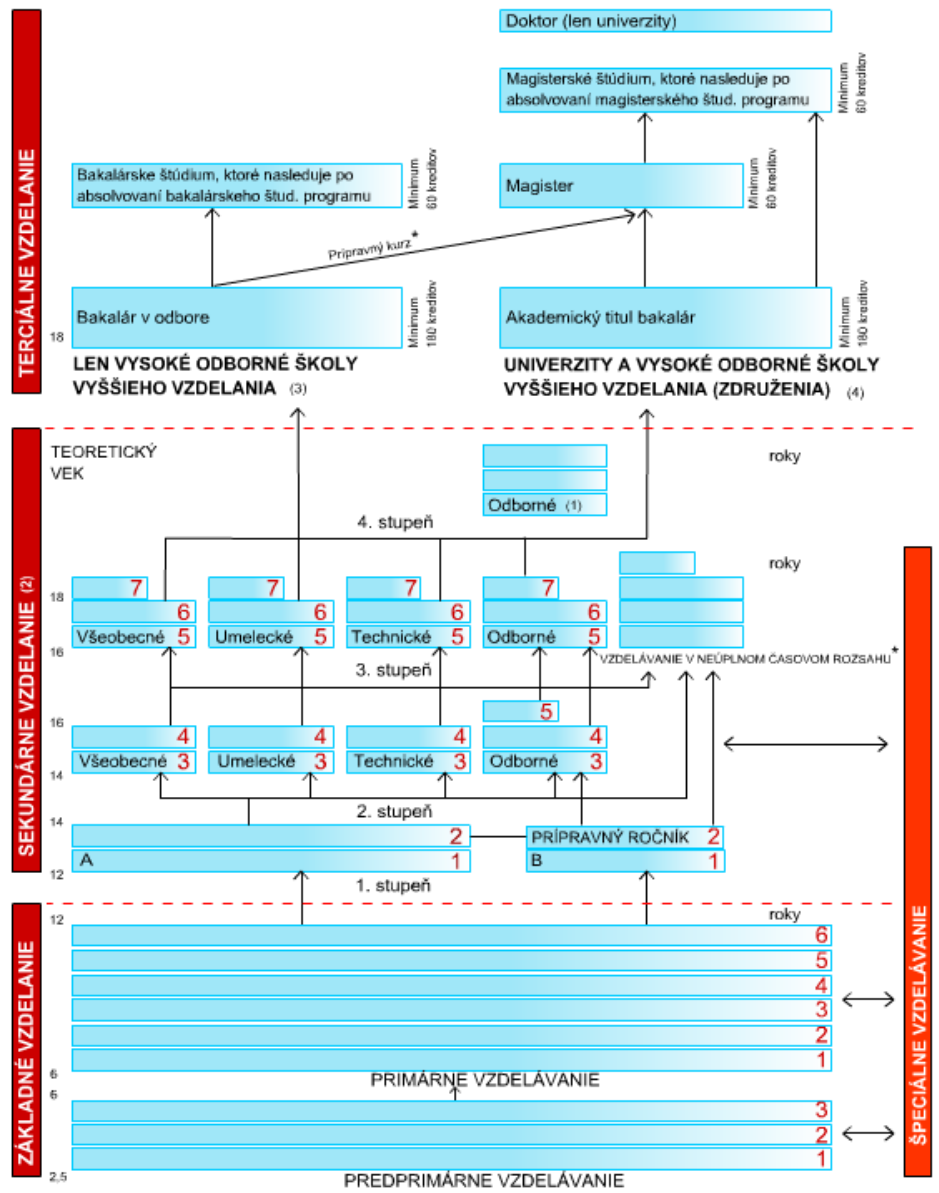

Vysvetlivky: (1) V̌̌etci študenti, ktorí úspešne absolvovali 2. ročník 3. stupňa alebo zložili vstupný integrovaný test, majú pristup $k 4$. stupňu stredného odborného vzdelania (postsekundárne vzdelanie). (2) Modulárne vzdelávanie nie je rozdelené na stupne a roky štúdia, a preto nie je zastúpené v diagrame. (3) Bývalé školiace programy jedného cyklu, ktoré boli poskytované vysokými odbornými školami vyššieho vzdelania boli od roku 2004-2005 transformované do odborných bakalárskych programov vzdelávania. (4) Dvojitý cyklus vzdelávacich kurzov vysokých odborných škôl kurzov a akademických kurzov na univerzitách bol od roku 2004-2005 transformovaný do akademických bakalárskych a magisterských programov vzdelávania. Tieto programy boli transformované z najmenej dvojročných kandidátskych kurzov a aspoň dvojročných licenčných kurzov do trojročných akademických bakalárskych programov, a aspoň jednoročných magisterských programov vzdelávania. Kandidátske stupne nie sú rovnocenné bakalárskym stupňom. *Vo veku od 15 alebo 16 rokov sa študenti môžu rozhodnút', či budú pokračovat' doterajšom spôsobe vzdelávania (organizovanom $v$ úplnom časovom rozsahu) alebo prejdú na vzdelávanie organizované v neúplnom časovom rozsahu, ktoré vyplýva z (BSO).

\section{Analýza začlenenia technických vyučovacích predmetov do učebných osnov}

V Belgicku, podobne ako na Slovensku predstavuje všeobecné technické vzdelávanie systém celoživotného vzdelávania, $\mathrm{v}$ rámci ktorého sa realizuje:

- v predškolskej výchove v MŠ,

- na primárnom stupni ZŠ v prvom a druhom ročníku $\mathrm{v}$ integrovanej podobe $\mathrm{v}$ rámci vyučovacích predmetov uvedeného stupňa vzdelávania a v tret’om až šiestom ročníku ako samostatný predmet svet práce - wereld orientatie,

- na nižšom sekundárnom stupni (prvý a druhý ročník prvého stupňa SŠ) v predmete technická výchova (od 1.9.2010 v predmete technika-techniek) [12], [13], [14], [15],

- na vyššom sekundárnom stupni (druhý a tretí stupeň SŠ v Belgicku) na SŠ so zameraním stredné technické vzdelanie (TSO) a stredné 
odborné vzdelanie (BSO) prehlbovaním poznatkov prostredníctvom odborného vzdelávania $\mathrm{v}$ oblasti techniky,

- na vysokých školách a univerzitách technického zamerania,

- podl'a ponúk ostatných vzdelávacích inštitúcií v rámci rôznych kurzov.

V roku 2008 bol na základe iniciatívy flámskej ministerky hospodárstva, podnikania, vedy, inovácií a zahraničného obchodu a flámskeho ministra práce, vzdelávania a odbornej prípravy vytvorený vládny projekt „Technika na školách 21. storočia“" (TOS21). Ciel'om projektu bolo zvýšit' záujem o vyučovanie $\mathrm{v}$ oblasti techniky u detí navštevujúcich predprimárny stupeň vzdelávania, až po študentov navštevujúcich TOBO (Technické vzdelávanie na primárnej úrovni) a TOSO (Technické vzdelávanie na stredoškolskej úrovni). V súlade s uvedeným ciel'om bol pretransformovaný systém technického vzdelávania na uvedených úrovniach. Na nižšom sekundárnom stupni (prvý a druhý ročník prvého stupňa SŠ) to spôsobilo zmeny, na základe ktorých bolo pôvodný vyučovací predmet technická výchova technologische opvoeding $\mathrm{v}$ školskom roku 2010/2011 nahradený vyučovacím predmetom technika - techniek, pričom časová dotácia novovytvoreného predmetu technika ostala nezmenená.

Technické vzdelávanie je na prvom stupni prúdu A (nižšie sekundárne vzdelávanie) v Belgicku realizované prostredníctvom predmetu technická výchova - technologische opvoeding (TO). V porovnaní so štandardným variantom učebných osnov v SR je zaradený do spoločnej časti vzdelávacieho programu pre prvý a druhý ročník prvého stupňa sekundárneho vzdelávania prúdu A s časovou dotáciou 2 vyučovacích hodín za týždeň. Hodinovú dotáciu uvedeného vyučovacieho predmetu je možné v závislosti od potrieb a orientácie konkrétnych SŠ navýšit' v prvom aj druhom ročníku sledovaného stupňa o 2 až 4 vyučovacie hodiny [12]. Zo schémy školského systému Belgicka (Obr. 1) je zrejmé, že prvý stupeň SŠ (nižšie sekundárne vzdelávanie) sa uskutočňuje prostredníctvom dvoch ročníkov $\mathrm{v}$ dvoch prúdoch (A a B). Technické vzdelávanie je v prúde $\mathrm{B}$ zabezpečované vyučovacím predmetom technická výchova $\mathrm{v}$ povinnej časovej dotácii 6 vyučovacích hodín týždenne počas celých dvoch rokov, pričom rovnako ako $\mathrm{v}$ prúde A, je možné uvedený rozsah navýšit' o $2-4$ vyučovacie hodiny [13]. Z uvedeného vyplýva, že $v$ rámci obidvoch prúdov (A aj $B$ ) sa technické vzdelávanie na nižšom sekundárnom stupni zabezpečuje vyučovacím predmetom technická výchova, ale v rozdielnej časovej dotácii. Vzhl'adom ku skutočnosti, že obsahová a realizačná stránka vyučovacieho predmetu technická výchova $\mathrm{v}$ prúde B sa podstatne líši od prúdu A, sa v d'alšej časti príspevku zameriavame na začlenenie vyučovacieho predmetu technická výchova a technika do učebných osnov príslušného stupňa vzdelávania len v prúde A.

Vzdelávací obsah predmetu technická výchova je rozdelený do 7 tematických okruhov, pričom každý z tematických okruhov má určený minimálny a maximálny počet vyučovacích hodín (Tab. 2).

Tab. 2: Časová dotácia tematických celkov v predmete technická výchova pre 1. a 2. ročník prvého stupňa prúdu A nižšieho sekundárneho vzdelávania [12]

\begin{tabular}{|c|l|c|}
\hline \multicolumn{1}{|c|}{ Tematický celok } & $\begin{array}{c}\text { Minimálny a maximálny počet } \\
\text { vyučovacích hodín }\end{array}$ \\
\hline $\mathbf{1 .}$ & Strojárstvo a stavebníctvo & 15 až 20 \\
$\mathbf{2 .}$ & Technológie a domácnost' & 30 až 40 \\
\hline $\mathbf{3 .}$ & Strojárstvo a doprava & 15 až 25 \\
\hline $\mathbf{4 .}$ & Technológie, informácie a komunikácia & 20 až 30 \\
\hline $\mathbf{5 .}$ & Technológie a zdravie & Technológie a výžva \\
\hline $\mathbf{6 .}$ & Technológie a energetika & \\
\hline
\end{tabular}

$\mathrm{V}$ rámci každého tematického celku sa vykonáva niekol'ko projektov, pričom však nie je potrebné zaoberat' sa všetkými položkami uvedenými v každom tematickom celku, aj ked' sa vždy odporúčajú využit'. Pri zostavovaní obsahovej náplne každého projektu je nutné klást' dôraz na medzipredmetové väzby a v prípade vhodnosti použitia sa obsah jednotlivých projektov môže doplnit' alebo previazat' s iným tematickým okruhom. Učebné osnovy preto môžeme považovat' za „otvorené osnovy“, to znamená, že je potrebné dosiahnut' minimálne tie ciele (vedomosti, zručnosti a postoje), ktoré sú stanovené v konkrétnom projekte. Je potrebné, 
aby učitel' plánoval, akým spôsobom využije IKT na konkrétnych hodinách, tak aby boli dosiahnuté stanovené ciele.

$\mathrm{V}$ rámci novokoncipovaného vyučovacieho predmetu technika, tvorcovia vzdelávacieho programu nepovažovali za podstatné uskutočňovat' zmeny časovej dotácie. Dôraz je podl'a nich potrebné klást' na spôsob realizácie sprostredkovania obsahu uvedeného vyučovacieho predmetu. $\mathrm{Na}$ učitel'ov sa kladú nároky, v zmysle ktorých majú pri sprostredkovávaní poznatkov na hodinách využivat' najmä koncepcie skupinového a kooperatívneho vyučovania, uplatňovanie projektového a problémového vyučovania, samostatná práca žiakov a pod. Z uvedeného vyplýva, že predmet technika je vo väčšej miere zameraný na praktické činnosti žiakov, získavanie pracovných skúseností a zručností v kl'účových oblastiach techniky.

Hodinová dotácia predmetu technika sa nezmenila, pričom u žiakov prvého a druhého ročníka prvého stupňa SŠ prúdu A je predmet technika zastúpený $\mathrm{v}$ časovej dotácii 2 vyučovacích hodín za týždeň. V prípade potreby si môžu SŠ povinnú dvojhodinovú dotáciu navýšit' o 2 až 4 vyučovacie hodiny [14].

Vzdelávacie stratégie predmetu technika vychádzajú zo všeobecných ciel'ov stanovených pre tento vyučovací predmet. Ciel'om uvedeného predmetu je u žiakov rozvíjat' schopnosti riešit' problémy; schopnosti uplatňovat' tvorivé nápady vo svojej práci; schopnosti preberat' zodpovednost' za svoju prácu; schopnosti byt' samostatným; schopnosti hodnotit' a vyjadrovat' vlastný názor; schopnosti sebapoznania a sebahodnotenia $\mathrm{v}$ smere vlastnej profesijnej orientácie; schopnosti flexibilne reagovat' na zmeny na trhu práce $\mathrm{v}$ snahe čo najlepšie sa uplatnit'.

V tabul'ke 3 uvádzame vymedzenie vzdelávacieho obsahu predmetu technika, ktorý je štruktúrovaný do 5 tematických okruhov s vymedzením maximálneho časového rozsahu pre konkrétnu oblast' vzdelávania.

Tab. 3: Časová dotácia tematických celkov v predmete technika pre 1. a 2. ročník prvého stupňa prúdu A nižšieho sekundárneho vzdelávania [14]

\begin{tabular}{|c|l|c|}
\hline & Tematický celok & Maximálny počet vyučovacích hodín \\
\hline $\mathbf{1 .}$ & Technológie a Energetika & 12 \\
\hline $\mathbf{2 .}$ & Technológie, informácie a komunikácia & 12 \\
\hline $\mathbf{3}$. & Technológie a Biochémia & 12 \\
\hline $\mathbf{4 .}$ & Technológie a Stavebníctvo & 12 \\
\hline $\mathbf{5 .}$ & Technológie a Doprava & 12 \\
\hline
\end{tabular}

Pri zostavovaní obsahovej náplne každého projektu príslušného tematického celku predmetu technika je nutné klást' dôraz na medzipredmetové väzby. Je vhodné z hl'adiska zvyšovania angažovanosti a záujmu žiakov o uvedený predmet, aby učitel' pri výbere vzdelávacieho obsahu rešpektoval záujmy žiakov. Taktiež sa odporúča sa, aby učitel' aplikoval do výučby na konkrétnych hodinách predmetu technika vhodným spôsobom prostriedky moderných informačnokomunikačných technológií.

\section{Záver}

Komparatívna analýza technického vzdelávania viacerých krajín Európskej únie jednoznačne ukázala, že aj napriek významnosti technického vzdelávania pretrváva uvedený trend poklesu záujmu o štúdium technického zamerania, a to nielen v Slovenskej republike, ale aj v krajinách Európskej únie, a nedarí sa ho zastavit' ani napriek snaženiam národných i medzinárodných inštitúcií. Slovenská republika, Belgicko, ako aj ostatné členské štáty Európskej únie sa stretávajú s narastajúcim nedostatkom kvalitne pripravených absolventov nižšieho sekundárneho stupňa $\mathrm{v}$ oblasti predmetov technického a prírodovedného zamerania. $\mathrm{Na}$ tento nedostatok $\mathrm{v}$ značnej miere vplýva kvalita vyučovania uvedených predmetov, čo sa v sekundárnej rovine prejavuje nielen $\mathrm{v}$ relatívnom poklese záujemcov o štúdium na takto orientovanom sekundárnom a terciálnom stupni vzdelávania, ale taktiež v nerovnováhe na trhu práce a v pracovných odvetviach technického a prírodovedného zamerania.

\section{Literatúra}

[1] NĚMEC, M. Fyzikálne vzdelávanie a akustika v kontexte školských reforiem. Dostupné na internete: 
didmattech.ektf.hu/data/present/115_present.doc [2010-90-09], s. 1.

[2] ZÁHOREC, J. Elektronické výučbové prostriedky $v$ technológii vzdelávania: dizertačná práca. Nitra: PF UKF. 2008.

[3] KOŽUCHOVÁ, M. Pracovná výchova a technické vzdelávanie na ZŠ. Bratislava: UK, 1993. Bez ISBN.

[4] Techniek op school voor de 21ste eeuw. 2011. Dostupné na internete:

http://www.ond.vlaanderen.be/tos21/ [2011-0430].

[5] VAN de VELDE, D. - HANSTON, P. From dualism towards an emphasis on talent: an overview of curriculum development in Flanders. Dostupné na internete:

http://www.iteaconnect.org/Conference/PATT/P ATT15/Velde.pdf [2011-03-18], s. 377-387.

[6] BORREY, S. Popularisation of Science, Technology and Innovation in Flanders. Dostupné na internete:

http://ec.europa.eu/research/conferences/2004/sci prof/cd/pdf/b_fland/popularisation_of_science_e n.pdf [2011-04-13].

[7] TOS 21. Dostupné na internete:

http://www.ond.vlaanderen.be/tos21/visietekst/T OS21_EINDRAPPORT_2008\%2008\%2027_Sy mposium.pdf [2011-02-10].

[8] KOZÍK, T. Prečo učit' techniku na základných školách a gymnáziách? In InEduTech. Prešov: FHaPV Prešovskej univerzity, 2007. ISBN 978-80-8068-612-3. Dostupné na internete:

http://www.pulib.sk/elpub2/FHPV/Pavelka2/inde x.html [2011-03-70], s. 38.

[9] LUKÁČOVÁ, D. - BÁNESZ, G. Premeny technického vzdelávania. Nitra: PF UKF, 2007. ISBN 978-8094-136-9.

[10] Education in Flanders. A broad view of the Flemish educational landscape 2008. Dostupné na internete:

http://www.ond.vlaanderen.be/publicaties/eDocs/ pdf/107.pdf [2009-10-30], s. 25.

[11] Organization of the educational system in the Flemish Community of Belgium 2009/2010. Dostupné na internete: http://eacea.ec.europa.eu/education/eurydice/doc uments/eurybase/eurybase_full_reports/BN_EN.p df [2009-09-03].

[12] Gemeenschapsonderwijs - secundair onderwijs A-stroom eerste graad eerste en tweede leerjaar (Technologische opvoeding). Dostupné na internete:

http://pedago.rago.be/pbddoc/lrplso/0405/2004-

001.pdf [2009-10-30], s. 2.

[13] Gemeenschapsonderwijs - secundair onderwijs B-stroom eerste graad eerste en tweede leerjaar (Technologische opvoeding). Dostupné na internete: http://pedago.rago.be/pbddoc/lrplso/0405/2004003.pdf [2009-10-30].

[14] Techniek eerste graad A-stroom (Leerplan secundair onderwijs VVKSO-BRUSSEL D/2010/7841/017 September 2010). Dostupné na internete:

http://ond.vvksoict.com/leerplannen/doc//Technie k-2010-017.pdf [2011-04-13].

[15] Techniek eerste graad B-stroom (Leerplan secundair onderwijs VVKSO-BRUSSEL D/2010/7841/020 September 2010). Dostupné na internete:http://ond.vvkso-

ict.com/leerplannen/doc/Techniek-2010-020.pdf [2011-04-13].

Mgr. Adriana Nagyová

Katedra techniky a informačných technológií

Pedagogická fakulta UKF v Nitre

Dražovská cesta 4

949 74, Nitra, SR

Tel: +421 376408343

E-mail: adriana.nagyova@ukf.sk

www pracoviska: www.pf.ukf.sk

PaedDr. Ján Záhorec, PhD.

Katedra informatiky

Fakulta ekonomiky a manažmentu SPU v Nitre

Tr. A. Hlinku 2

949 76, Nitra, SR

Tel: +421 376414196

E-mail: jan.zahorec@fem.uniag.sk www pracoviska: www.fem.uniag.sk 